Chapter 20

\title{
Immune Intervention in Type I Diabetes Mellitus
}

\author{
Johnny Ludvigsson
}

Additional information is available at the end of the chapter

http://dx.doi.org/10.5772/52801

\section{Introduction}

In many countries Type 1 diabetes [T1D] is the most common life-threatening disease in children, and nobody can be cured. For long time the incidence has increased all over the world [1]. The disease causes serious morbidity and increased mortality [2,3] in spite of an intensive treatment with multiple daily injections of insulin, adapted to regular meals with suitable content based on self-monitoring of blood glucose. Many patients do never succed to get good metabolic control because of the complicated treatment and another problem preventing good metabolic control is hypoglycaemia [4]. Modern insulin pumps and glucose sensors have made it possible to improve insulin treatment [5]. The simplest approach to reduce severity of hypoglycemia when treatment is intensified is to interrupt insulin delivery. There are insulin pumps with an integrated continuous glucose monitoring, which automatically suspends insulin delivery for up to 2 hours when hypoglycemia is detected even when the hypoglycemia alarm is not acknowledged by the patient $[6,7]$. Closed-loop insulin delivery [artificial pancreas] is aiming to achieve near normal blood glucose without increasing the risk of hypoglycemia [8]. Thus a disposable sensor measures interstitial glucose levels, which are fed into an algorithm controlling delivery of a rapid-acting insulin analog into the subcutaneous tissue by an insulin pump. So far research has focused on closed loop insulin delivery during night, and this technique is improving [9]. However, also in the future there will be need for the patient to learn how to handle also these devices, not least during infections, longer exercise, and several other situations and changes of life.

\section{Introduction}

Even though patients with T1D need insulin, the primary goal of novel therapies is to preserve residual insulin secretion, in best case to cure diabetes or at least to make the disease milder 
and facilitate treatment. Patients with residual insulin secretion usually get lower $\mathrm{HbA1c}$, and residual insulin secretion facilitates the treatment, decreases the risk for serious hypoglycaemia and the risk of keto-acidosis [10]. Already very modest beta cell function, with peak stimulated C-peptide above $0.2 \mathrm{nmol} / \mathrm{L}$ seems to reduce long-term complications [11]. Furthermore, Cpeptide per se has been proposed to decrease the risk of complications, especially neuropathy. There is increasing evidence that C-peptide is not just a connecting peptide to keep the two insulin chains in in a certain structure, but a hormone with several important effects [12]. The relevance of saving beta cells and improving their function has become even more evident when studies suggest that beta cells may regenerate [13,14]. If this is the case an end of the destructive process might lead to cure of T1D [15].

\section{The immunological disease process}

The generally accepted opinion is that the majority of the pancreatic beta cells are lost at the diagnosis of Type 1 diabetes. The beta cells are supposed to be killed by an autoimmune process precipitated and promoted by genetic and environmental factors. In recent years the dogma saying that most beta cells are dead has been questioned, and regeneration of the beta cells seems not only possible but quite plausible. Actually that was discussed as a possibility already several decades ago( Fig 1). Thus, many beta cells may still be living in pancreas although they do not respond normally to stimulus with insulin secretion. Auto-antibodies are usually found, but regarded as markers of the process, rather than causing beta cell death. The auto-antibodies react against the islet cells (Islet Cell Antibodies; ICA) [16] or against specific auto-antigens such as Insulin Auto-antibodies against Insulin (IAA) [17], against Glutamic Acid Decarboxylase (GADA) [18], against Tyrosin Phosphatase ( IA-2A) [19] or against ZincTransport Antigen (ZnTA) [20]. These antigens are attacked by the own immune system. Dysregulation of the immune system is thought to allow a self-destructive process. Mononuclear cells, mainly T-cells, seem to play the most important role for the killing of the beta cells.

\section{Immune interventions}

Several immune interventions have been tried since the 1970ies we tried plasmapheresis in Linköping, Sweden, with the aim to preserve residual beta cell function, but so far all different approaches have shown insufficient efficacy and/or given unacceptable adverse effects [21-28]. Broad immunosuppressive or immunoblocking therapies with steroids, cytostatics, high doses of immunoglubulins, anti-lymphocyte globulins have shown some but unfortunately limited efficacy, and adverse events have lead to restrictions both in dose and time. Our studies using photopheresis did show some efficacy, and although the treatment was very laborious it has regained some interest. However, most encouraging is the use of monocloncal antibodies, especially against CD-3 [29-31] but also against CD-20 [32]. Unfortunately treatment with monoclonal antibodies in doses large enough to give efficacy also cause rather common and occasionally serious adverse events. Therefore such therapies are rarely justified as preventive 
interventions in healthy children with increased risk of developing T1D except for children with extremely high risk of developing T1D close in time.

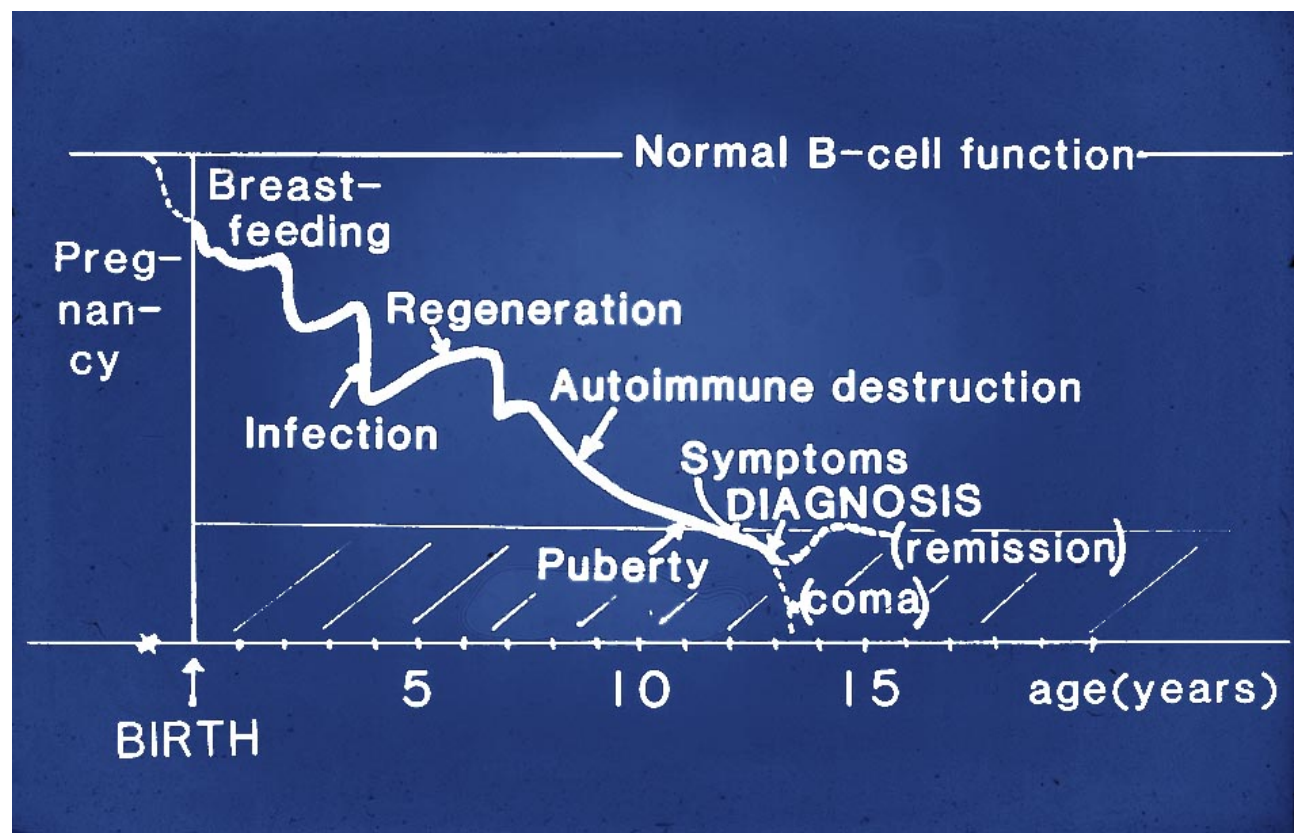

Figure 1. At a Nordic symposium in connection with Annual meeting of Scandinavian Society for the Study of Diabetes, Linköping 1981, the author showed this slide. Type 1 diabetes was proposed to develop after a long autoimmune process destroying the beta cells. Events during pregnancy and the importance of breast-feeding was suggested, and later shown to be relevant, and regeneration of beta cells was proposed as a possibility.

After encouraging Phase II trials two different Phase III trials using antiCD3 failed to reach their primary endpoints [33,34], but one of them, the Protégé study, did show efficacy in younger patients age 8-18 years when a reasonably high dose of antiCD-3 was used [34]. This was especially true in certain patient populations (mainly patients in USA, but also in Europe) who had rather well preserved C-peptide, often near-normal $\mathrm{HbA} 1 \mathrm{c}$ and low insulin requirement. Further studies are needed to learn what doses are efficient without severe adverse events, and in what patient populations the treatment works best. The old policy defended by many diabetologists to treat all so called T1D in the same way irrespective of age, ethnic background, severity of disease at diagnosis etc may probably have to be left.

\section{Vaccines against infections}

Traditional vaccinations could either contribute to the development of T1D, or T1D could be prevented by vaccination. Already in the 1920ies mumps infection was shown to be a possible 
cause of insulin dependet diabetes [35]. A general vaccination against mumps might then either decrease the incidence of T1D, or vaccination with living virus might on the contrary initiate an autoimmune process leading to an increased incidence of T1D. None of these associations have been proven [36, 37]. Neither have there been any associations between vaccinations against other microbes and the development of diabetes [38]

Entero virus infections are most suspected to cause T1D. Epidemiological studies have provided evidence of coxsackie virus (CVB) infections in subjects who later develop T1D [39]. A CVBB4 strain E2 was isolated from pancreas of a diabetic child, and the virus was then passed into islet cells and found to cause diabetes in mice, which was taken as a proof of the concept that coxsackievirus can cause T1D [40]. So far vaccination against these types of infections to preserve beta cells has been disappointing,

The hygiene hypothesis suggests that the immune system would deviate less often towards an autoimmune process if the immune system was occupied by an ongoing defence against serious enemies. In accordance with this hypothesis, Calmette vaccination has been tried to preserve beta cell function but no clinical effect has been seen [41].

\section{Immune intervention by probiotics}

Several findings indicate that the gut is involved in the development of the disease process leading to T1D [42]. The intestinal barrier may be disturbed. This might facilitate passage of proteins which could contribute to the autoimmune process. Cows milk [43], and bovine insulin in cows milk has been suggested as a possible cause of an autoimmune reaction against insulin [44]. Maturation of the immune system may also be influenced by the gut flora. Probiotics can probably influence immune function through effects on antigen-presenting cells, regulatory $\mathrm{T}$ cells and effector $\mathrm{T}$ and $\mathrm{B}$ cells [45] and probiotics may prevent autoimmune diabetes in NOD mice [46,47]. However, although use of probiotics would be attractive as the adverse events can be expected to be minimal, there are so far no studies proving any effect

\section{Heat shock protein used in immune intervention}

Studies in experimental animals have shown that use of a $65-\mathrm{kDa}$ heat shock protein can prevent diabetes [48]. A specific peptide, Diapep 277, seems to be the active component and this peptide has been tried with interesting effects.

Clinical trials in humans have shown that sc administration of Diapep 277 may preserve beta cell function in adults [49]. Thus 35 patients with type 1 diabetes and basal C-peptide above $0.1 \mathrm{nmol} / \mathrm{L}$ were assigned to subcutaneous injections of $1 \mathrm{mg}$ Diapep277 and $40 \mathrm{mg}$ mannitol in vegetable oil The primary endpoint was glucagon-stimulated C-peptide production. At 10 months, mean C-peptide concentrations had fallen in the placebo group $(n=16)$ but were maintained in the DiaPep277 group $(n=15 ; \mathrm{p}=0.039)$. Need for exogenous insulin was higher in the 
placebo than in the DiaPep277 group. There were no o adverse events. The treatment of newly diagnosed T1D adults with DiaPep277 seemed to preserve residual insulin secretion through induction of a shift from Thr- 1 to Thr- 2 cytokines. However, the efficacy seen in adults could not be confirmed in children and adolescents with T1D [50,51] in spite of interesting immunologeval results [52]. In a recent Phase III trial no immunological difference could be found between adults treated with Diapep 277 or those treated with placebo [53]. Treatment with Diapep 277 seemed to preserve C.peptide but only C-peptide after Glucagon stimulation, but not after Mixed Meal Tolerance Test [54]. Thus it is still unclear whether Diapep 277 has a place or not as future intervention to preserve residual insulin secretion in adults.

\section{8. “Inverse vaccination "to reduce the immune response}

Traditional vaccination is strengthening the immune reaction against an antigen, usually an infectious microbe. Methods of reducing a pathological specific immune response eg in autoimmune diseases like T1D can be regarded as a sort of "inverse" vaccination. In allergy tolerance against the allergens is created by presenting the antigen/allergen/s in gradually increasing doses. Such Immunotherapy has become quite efficacious [55] and the adverse events are rare.

It would be reasonable to try to reduce an autoimmune process in an analogue way, by administration of auto-antigen/s. Thus, instead of suppressing the immune system, the immune response should be modulated by presenting antigen/s in a way that the immune system shifts from a destructive process to tolerance [56].

If self-reactive T-cells directed against auto-antigens cause some cases of Type 1 diabetes a major question is why such self-reactive T-cells occur. Two mechanisms seem to be necessary for self-tolerance: Clonal deletion of self-reactive T-cells issued from the random recombination of genes (negative selection), and generation of self-antigen-specific natural regulatory Tcells (Tregs) which can inactivate self-reactive T-cells in the periphery when they have escaped intra-thymic negative selection [57]. In T1D auto-reactivity against insulin is a common and early phenomenon. The important role of thymic insulin for development of self-tolerance has been demonstrated in transgenic mice [58], but there is still no technique to use this knowledge in clinical practice.

\section{Auto-antigen treatment}

\section{1. "Vaccination" with insulin}

Proinsulin and insulin and its different chains are so far the only known auto-antigens that are specific for the beta cells. Insulin has been used in trials to prevent diabetes among first degree relatives with increased risk of T1D. In Diabetes Prevention Trial-Type 1 Diabetes (DPT-1) human ultralente insulin of 0.25 units $x \mathrm{~kg} /$ day, or placebo, was given to subjects with $>50 \%$ 
5-year risk of getting T1D. To give such large doses of insulin sc every day can not be regarded as immune intervention, but rather as beta cell support. In any case this type of treatment failed to reach the end-point [59].

Oral insulin is not supposed to be absorbed enough to affect blood glucose or to support remaining beta cells, but such an administration can be regarded as immune intervention. The DPT-1 trial randomized 372 relatives of subjects with T1D, positive for IAA and with normal intravenous and oral glucose tolerance test (IVGTTs and OGTTs), to oral insulin $7.5 \mathrm{mg}$ daily or placebo. Although the result was negative when comparing the groups with the pre-specified inclusion criteria, subanalyses suggested that Type 1 diabetes was significantly delayed in those individuals who had higher concentrations of IAA [60]. This suggests that auto-antigen therapy may be most efficaceous in patients whose immune system reacts strongly against a certain antigen.

The first diabetes-related auto-antibodies in young children are usually IAA and therefore insulin has been tried to prevent diabetes in high risk individuals. Intranasal proinsulin had effect in experimental animals [61] but intranasal administration of insulin in high risk children had no effect [62]. Administration of the insulin B-chain can prevent diabetes in experimental animals [63]. A combination of the insulin B-chain fragment with Freunds adjuvant has been tried also in newly-diagnosed T1D adults [64]. There was effect on T-regulatory cells but no significant effect on C-peptide.

\subsection{GAD-vaccination}

During our studies with plasmapheresis [21] we discovered a new diabetes-related antigen, $64 \mathrm{kD}$ [65], which later on was found to be glutamic acid decarboxylase (GAD [66]. Auto-antibodies towards GAD are common in T1D and there are convincing results from studies of experimental animals that treatment with GAD can prevent autoimmune diabetes $[67,68]$..

An adjuvanted formulation, based on Alhydrogel ${ }^{\circledR}$, a product of Aluminum hydroxide (alum), was developed to provide a drug (Diamyd ${ }^{\circledR}$ ) used for evaluation in clinical trials. Alhydrogel ${ }^{\circledR}$ is used as adjuvant in vaccines for children eg DTP, Pneumococcal conjugate, Hepatitis B, Hepatitis A vaccines. Aluminum salts are inducing a humoral (Th2) rather than cellular immune response. As the T1D autoimmune process is deviated towards Th1 (or cellular) response to autoantigens, alum is used to counteract this deviation and "steer" the response induced by GAD away towards a Th2 response. Inclusion of adjuvant is also a way to minimize the quantity of antigen required for treatment.

Diamyd ${ }^{\circledR}$ preclinical safety studies were done and caused no concerns for clinical safety. Evaluation of the effects of Diamyd ${ }^{\circledR}$ in several different animal models of autoimmune disease did not indicate any undesirable effects on the immune system. Phase 1 studies in humans were performed 1999.A randomized, double-blind and placebo-controlled dose-finding Phase IIa study in 47 LADA demonstrated efficacy in beta cell preservation in the 20- $\mu$ g group [60] There were no Serious Adverse Events (SAEs) ) and even though the number of patients was very small, this result was encouraging. Follow-up after five years completed 2008 still showed 
a significantly beneficial effect of the $20 \mu \mathrm{g}$ dose of Diamyd $\AA$, and there had been very few $A E$, none of them considered to be treatment related [70]

A Phase IIb, randomized, double-blind, placebo-controlled multicenter Diamyd $\AA$ study in 160 LADA-subjects was then performed in Sweden. Subjects received $20 \mu \mathrm{g}$ of GAD65 or placebo on 2 occasions 4 weeks apart. The trial had a main study period of 18 months and was scheduled for unblinding in June 2007. Unfortunately, the study had to be invalidated due to concerns regarding the labeling process of the investigational product. No safety concerns were raised and no SAEs had been observed during 30 months observation.

\subsection{GAD vaccination in children and adolescents}

To investigate safety and efficacy of Diamyd ${ }^{\circledR}$ in T1D, a Phase II clinical trial in 70 recently diagnosed T1D children and adolescents was performed [71]. The study was a randomized, double-blind, placebo-controlled multicenter study using the same dose regimen as in the successful group of the previous LADA trial. The main study period of 15 months was completed and the trial partly unblinded for sponsor and statistician but continued blinded for all other investigators for another 15 month follow-up. Outcomes from this study provided support for clinical safety and efficacy after administration of Diamyd $₫$. The treatment was very well tolerated and there were no treatment-related adverse events reported still after more than 4 years follow-up. Both treatment groups showed a gradual decline from baseline of both fasting and stimulated C-peptide secretion. There was no significant effect of treatment on change in fasting C-peptide after 15 months (primary endpoint). However, there was a significant efficacy seen on change in fasting $C$-peptide after 30 months $(p=0.045)$, which remained signficant when change in C-peptide/plasma glucose ratio was taken into account ( $p=0.02$ ). Furthermore, stimulated C-peptide secretion, as measured by area under the curve (AUC), decreased significantly less in the GAD-alum treated group compared to the placebo group, both after 15 months ( $\mathrm{p}=0.01)$ and after 30 months $(\mathrm{p}=0.04)$. The significant effect of treatment as change in fasting and stimulated C-peptide at month 30 remained when adjusting for duration of diabetes, age, gender, and baseline GADA levels.

However, although the c-peptide preservation was evident the insulin requirement in both treatment groups increased in the course of the study, and $\mathrm{HbA1c}$, and plasma glucose levels increased during the study. HbA1c did not differ between the groups.

Duration of diabetes was very important for the efficacy of treatment ( $\mathrm{p}=0.05$ for fasting at month 30 and $p=0.03$ for stimulated C-peptide area under the curve at month 15 and 30). In patients treated within 6 months of diagnosis both fasting and stimulated C-peptide secretion (AUC), decreased significantly less in the GAD-alum treated group as compared to the placebo group over 30 months (fasting, $\mathrm{p}=0.03$, and stimulated $\mathrm{p}=0.04$ ) while no such difference was seen in patients with a longer duration of diabetes ( Fig 2). The treatment effect in the short duration was still seen after more than 4 years follow-up [72] in patients with $<6$ months duration of diabetes at treatment. There were no treatment-related adverse events. 

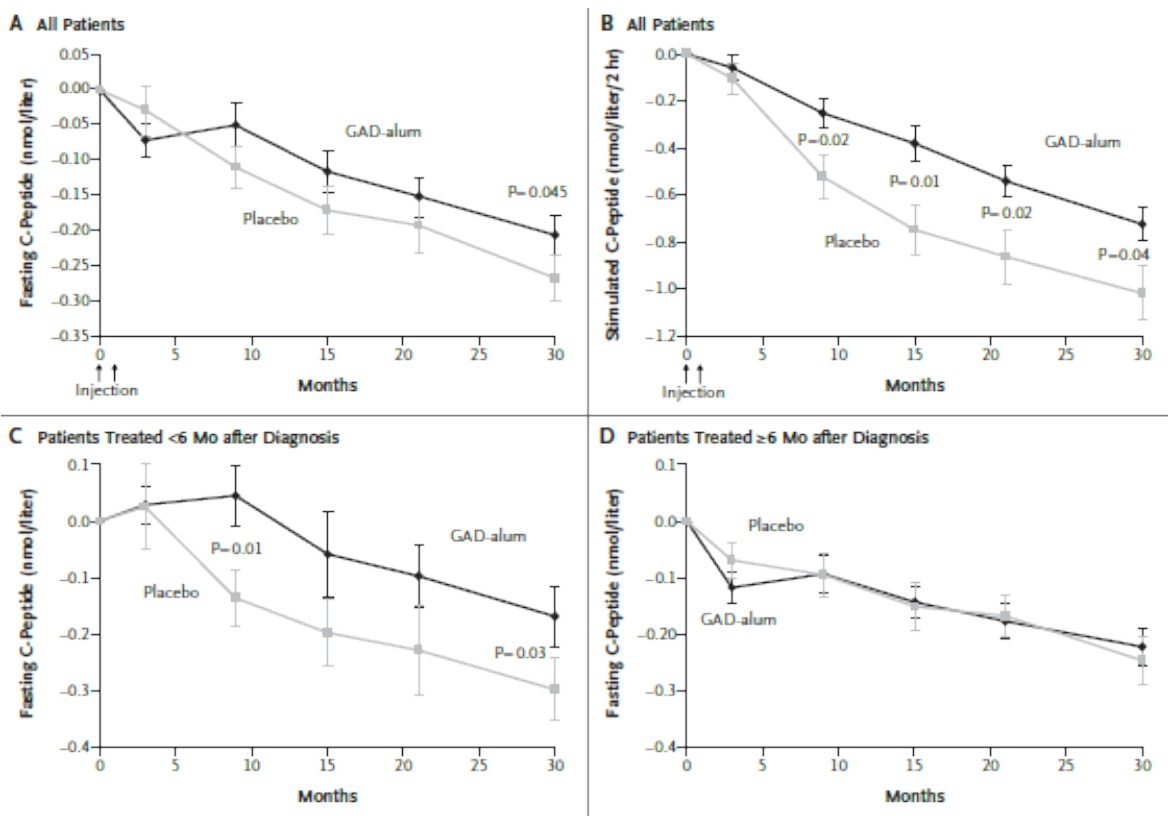

D Patients Treated 26 Mo after Diagnosis
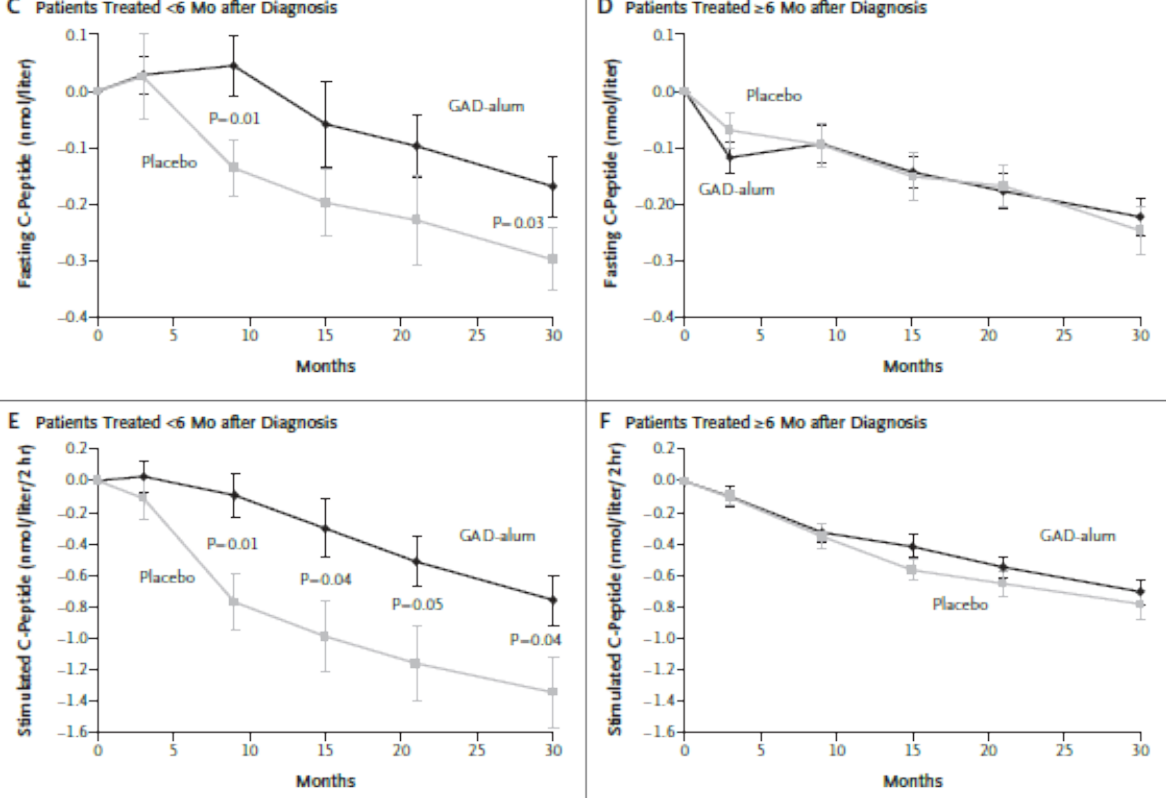

Mean changes from baseline in fasting (panelA) and stimulating (Panel B) c-peptide are fiven for all patients included in intention to treat analyses in the group receiving the recombinant human $65-\mathrm{kD}$ isoform of glutamic acid decarboxulase in a standard vaccine formulation with alum (GAD-alum. 35 patients) and in the group receiving placebo (34 patients). Mean changes from baseline in fasting (Panel C) and stimulated (Panel E) C-peptide levels are also shown for those patienst treated less then 6 month after receiving the diagnosis of diabetes ( 11 patients in GAD-alum group and 14 patients in the placebo group). Finally, mean changes from baseline in fasting (Panel D) and stimulated (Panel F) Cpeptide levels are shown for those treated 6 months or more after diagnosis ( 24 patients in the GAD-alum group and 20 patients in the placebo group). Stimulated C-peptide level was measured on the basis of areas under the curve in response to the mixed-meal tolerance test. I bars indicate standard errors. To convert values for C-peptide to nanograms per milimeter, devided by 0.33 .

Figure 2. Mean Changes from Baseline Levels of Fasting and Stimulating C-Peptide, According to Treatment Group and Time of Treatment Relative to Diagnosis.

The Phase II trial was followed by aPhase III trial in Europe. 334 patients age 10- 20 years were included, with diabetes duration $<3$ months at screening, fasting C-peptide $>0.1 \mathrm{nmol} / \mathrm{l}$ and 
pos GADA. In this study the two arms of the Phase II study ( placebo resp $20 \mu \mathrm{g}$ of GAD65 (Diamyd ${ }^{\circledR}$ ) with 30 days interval, were the same, but in addition there was a third arm where the patients got $20 \mu \mathrm{g}$ of GAD65 (Diamyd( ${ }^{\circledR}$ ) sc also at Day 90 and 270 when the patients in the other arms got placebo injections. The primary endpoint was difference in C-peptide AUC after a Mixed Meal Tolerance Test. Surprisingly the study failed! [73]. The difference in AUC was only $16-18 \%$ between the actively treated patients and the placebo group $(p=0.10)$ and the difference in fasting $C$-peptide was similar ( $p=0.07)$. However, in several prespecified subgroups the efficacy was quite pronounced (around 30-40\%), and significant.. When combining Phase II and that arm in Phase III in which the patients received 2 doses of GAD-alum, then theefficacy measured both as fasting C-peptide and AUC after MMTT seems quite impressive after 30 months.

The question arises why the results in Phase III was so much weaker than in Phase II. There are some possible explanations: In Phase III the patients who received active drug by chance were more often 10-11 years old whereas patients in the placebo group more frequently were 16-20 years old than in the actively treated arms. It is well known that younger patients loose their residual insulin secretion more rapidly and therefore this difference in ages might have influenced the result. There are also other facts which may have played a role. Thus, in the Phase II trial the patients were treated in March -April and when looking at patients in Phase III who were treated in March-April there was in fact also significant effect of GAD-treatment. Finally, in the Phase II trial no vaccinations were accepted, but in Phase III Influenza-vaccination was allowed. Unfortunately an epidemic of H1N1-flu lead to that almost all patients were vaccinated, many of them in connection with the GAD-vaccinations. In Sweden and Finland the vaccine contained squalen, suspected to influence the immune system towards auto-immunity, and in these two countries there was no efficacy of GAD-treatment, while there was efficacy in other European countries. Patients in Sweden, who did not get the influenza vaccination close to the GAD-treatment, had better effect of the GAD-treatment [73].

\subsection{GAD-vaccination and the immune system}

In both the Phase IIb and the European Phase III patients treated with two doses of GAD-alum got increasing GADA levels with a maximum after 3 months and then a gradual decrease even if the concentrations of GADA remained significantly higher than in the placebo group. Four doses given in the Phase III trial lead to even higher GADA levels. Increase of GADA had neither relationship to efficacy of the vaccination, nor to adverse events. There was no change of epitopes related to development of Stiff Person Syndrome, but a rather small but significant shift in isotypes with reduced percentage of IgG1 and increased IgG3/IgG4 detected in GADalum treated patients[74], in agreement with a Th2 deviation. Spontaneous/non-stimulated and PHA-induced secretion of all cytokines was similar in samples from children receiving GAD-alum and placebo, both before and 15 months after the first injection. Cytokine secretion of IL-5, IL-10, IL-13, IL-17, IFN- $\gamma$ and TNF- $\alpha$, but not of IL- 6 and IL-12, in response to in vitro stimulation with GAD65 increased in GAD-alum treated patients from baseline to month 15, but a continuous increase was only seen in IL-5, IL-10 and IL-13 while other cytokines remained elevated but at a stable concentration [75]. This indicates that the treatment caused a Th2- 
deviation. The immunological effects were long lasting immune responses, as they remained still 48 months after the first injection [75].

As a sign of increase of T-regulatory cells we noticed an increased GAD65-induced expression of FOXP3 and TGF- $\beta$ at month 15 in cells from GAD-alum treated patients compared to placebo, and the expression of FOXP3 and TGF- $\beta$ correlated positively in the GAD-alum group but not in the placebo group[77]. Still after 48 months there were clear effects on the immune system suggesting both a Th2 deviation, a decrease of activated T-cells (CD4+CD25+high) but increase of FoxP3-positive regulatory T-cells. Thus, our interpretation is that Diamyd ${ }^{\circledR}$ treatment deviated the immune system towards tolerance against the auto-antigen GAD.

\subsection{Other trials with GAD vaccination}

Beside the European phase III trial discussed above [73], a similar trial was started a bit later in USA (US Phase III ClinicalTrials.gov Identifier: NCT00751842 ;Jerry Palmer, PI), with the same design. The recruitment was not so fast as initially only patients $>16$ years old were accepted, and therefore the recruitment had just finished when the negative results of the European Phase III trial was found. This lead to that the American trial was stopped, before it can give any results. In addition another intervention trial in newly-diagnosed Type 1 diabetic patients aged 3-45 years was performed by TrialNet (TrialNet Intervention ClinicalTrials.gov Identifier: NCT00529399). Patients were randomized in a double-blind controlled study into three arms, one with subcutaneous injections of $20 \mu \mathrm{g}$ GAD65-alum (Diamyd®) at day 1,30 and 90, a second arm with subcutaneous injections of $20 \mu \mathrm{g}$ GAD65-alum (Diamyd ${ }^{\circledR}$ ) at day 1,30 and placebo at day 90, and a third arm with placebo at all time points The study failed. No effect on C-peptide preservation was found [77]. So far little has been presented from this trial with regard to effects on the immune system. It is difficult to know what the wide age range, variation in ethnic groups, BMI etc meant for the result.

\subsection{Ongoing or planned GAD-alum studies}

Because of the positive results in the Swedish Phase II study and the positive results in some prespecified subgroups in the European Phase III trial, new studies are planned. As the Phase III trial failed, GAD-alum will be given as part of combination therapy, which hopefully will give a better effect on the disease process. Thus a new pilot trial is just on its way when GADalum is combined with Vitamin D, which is supposed to positively influence the dendritic cells, contribute to Th2 deviation, but also influence directly beta cell survival and insulin sensitivity. In addition a third drug, anti-inflammatory, will be given to dampen the inflammation, which might play an important and negative role beside the autoimmune process.

In addition to interventional trials at onset of Type 1 diabetes a pilot trial with the aim to prevent T1D is ongoing in southern Sweden. High risk children have been identified as part of the so called DiPiS (Diabetes Prevention in Skåne) study, in which newborn children in the general population have been screened for auto-antibodies. Children positive for GADA, plus at least one more diabetes-related autoantibody, have been treated with either $20 \mu \mathrm{g}$ GAD65-alum 
(Diamyd ${ }^{\circledR}$ ) or placebo subcutaneous at day 1 and 30 . As the study is not powered for efficacy the main aim is to study safety.

\section{DNA vaccines}

T-cells respond to antigens presented by antigen presenting cells (APCs).DNA-vaccines can be used to present the antigen instead of delivering intact proteins. A protein encoded by a plasmid DNA can either be produced outside the APCs if the pasmidDNA is administered into a muscle, or the plasmidDNA may be taken up by the APCs where the encoded protein is presented [78]. Proteins encoded by DNA vaccines can induce different types of antigenspecific immune responses, and perhaps also some non-specific reactions.

Most common routes of administration are either intramuscular, which is thought to favour Th1 responses, or intradermal, which is thought to favour Th2 response. For treatment of Type 1 diabetes intradermal injection should be most interesting. Another way of skewing the response towards Th2 may be to co-administer plasmids encoding Th2 cytokines.

Promoters from virus, eg Cytomegalovirus, can be used. Certain sequences seem to stimulate Th1 response and should therefore be avoided in treatment of T1D.

So far DNA-vaccines to create tolerance in autoimmune disease have been tried mainly in experimental animals. Plasmid DNA encoding for proinsulin [79] as well as for the insulin B chain [80] have been used for prevention of diabetes in experimental animals. Injection of plasmidDNA encoding for GAD has been shown effective in preventing diabetes in NODmice [81], while similar effect have been seen by combining plasmidDNA encoding for a fusion protein consisting of both GAD, IgG and IL4 [82]. Treatment with a recombinant vaccinia virus expressing GAD ( $r V V-G A D 65$ ) has also shown to be effective in prevention of autoimmune diabetes in NOD mice by induction of active suppression of effector T-cells [83]. IgG1 antibodies and IL-4 increased and the IgG2 was unchanged, suggesting a Th2 deviation.Before clinical use there are several problems which need to be solved. Correct dosing is necessary as wrong dose might give increased immune response and a more aggressive disease process In addition it is important to be sure that the DNA is not integrated in the host chromosome. Another problem might be production of antibodies against DNA.

\section{Beta cell regeneration}

The traditional generally accepted view is that when a patient gets Type 1 diabetes there is no longer any capacity of the beta cells to regenerate. However, there are almost no studies on beta cell regeneration in humans. In recent years some studies suggest that the old paradigm may be wrong and that beta cells in fact can regenerate. GLP-1 might stimulate beta cell regeneration.and GLP-1 agonist (Exenatide) in combination with monoclonal antibodies interfering with IL-2 ( Daclizumab) was given to patients with longstanding Type 1 diabetes with 
some residual insulin secretion, to see whether the treatment could increase C-peptide, but in this study the result was negative [84].

Administration of INGAP (islet neogeneis associated protein)in anaimals has caused increased beta cell mass and reversal of hyperglycemia, and hopefully INGAP has regenerating capacity in humans. Daily introductionf of INGAP or placebo has been tried in a double-blind randomized trial in both Type 1 and Type 2 diabetic patients [85], and it showed increased argininstimulated C-peptide during the treatment period, but the effect was very short. Already after 30 days the effect was lost, which does not indicate any influence on beta cell mass as such an effect should have been much longer

\section{Vitamin $\mathrm{D}$ and type 1 diabetes}

Experimental studies suggest that vitamin D may play a role in the defence against type 1 diabetes as well as type 2 diabetes. Epidemiological data suggest that there is a link between vitamin D deficiency and an increased incidence of Type 1 diabetes. A multinational casecontrol study and a birth cohort follow-up study from Finland [86] have concluded that vitamin D3 supplementation at birth protects against type 1 diabetes later in life, and a metaanalysis supports similar conclusions [87]. Low serum levels of $1 \alpha, 25$-dihydroxyvitamin D3 $[1,25(\mathrm{OH}) 2 \mathrm{D} 3$, calcitriol] has been found in patients with recently diagnosed type 1 diabetes. The protective effects of vitamin $\mathrm{D}$ against diabetes are mediated through the regulation of several components such as the immune system and calcium homeostasis. Thus, mechanistic studies show that 1,25(OH)2D3 modulates dendritic cell maturationand facilitates a shift from a Th1 to a Th2 immune response. There is also ncreasingevidence suggesting that vitamin D also affects beta cells directly thereby rendering them more resistant to cellular stress. There are results indicating that Vitamin D may also improve insulin sensitivity, which in turn decrease beta cell stress.

Vitamin $\mathrm{D}$ has been used in patients with recent onset Type 1 diabetes in an effort to preserve residual insulin secretion. However, so far Vitamin D alone has not been efficacious [88. 89]. It seems resaonable to try Vitamin D, both in higher dose, and in combination with other therapy.

\section{Anti-inflammatory treatment}

In diabetes, both Type 1 and Type 2, there are signs of inflammation, partly related to glucotixicity, partly to other traits of the disease. Thus also in Type 1 diabetes there is an inflammatory componenent in addition to the autoimmune process. IL- 1 has been proposed to be of special importance for the destruction of pancreatic beta cells [90], and blocking IL-1 in experimental animals has shown important effects on the disease process. Use of IL-1 inhibitor in Type 1 diabetes has shown reduced serum interleukin 8 (IL-8) levels and reduced CD11b integrin expression on monocytes associated with increased CXCR1 expression. These effects suggest that blocking the IL-1beta pathway results in a reduced ability of mononuclear cells 
to go to sites of inflammation. However, there is a great gap between studies in animals and and in vitro mechanistic studies, to clinical studies in humans. Recently at the Congress of American Diabetes Association and at the Immunology Diabetes Society the results of two trials blocking the effect of IL-1 in Type 1 diabetes failed. Thus, the use of IL-1r-antagonist showed no effect on preservation of C-peptide or any related clinical parameter[91], and the same was unfortunately the case in another Phase II trial using a IL-1 antagonist, Anakinra [92]. Furthermore blocking IL-1 caused adverse events. Thus, as single therapy using anti-inflammatory drugs is not good enough, but should be tested in combination with other therapies.

\section{Future perspectives of immune intervention}

No single therapy has shown to be an effective immune intervention in manifest Type 1 diabetes for preservation of residual insulin secretion. As well as successful treatment of childhood leukemia and cancers needed combination of several drugs, it will most probably be necessary to use combination therapies also for Type 1 diabetes. Auto-antigen treatment will probably be part of such future clinical treatment and/or prevention of Type 1 diabetes. Even though GAD-alum so far has not shown any stable efficacy, and Diapep 277 has shown slight efficacy only in adults with good C-peptide preservation, future studies will tell us how to use auto-antigen therapy more effectively, and then in combination with other therapiesIt may be so that treatment with GAD may be useful in patients with immune recognition of GAD, and treatment with proinsulin or insulin/insulin chains may be useful in patients whose immune system recognizes these auto-antigens. Furthermore, the effect might be improved by combination therapies with eg Vitamin D, anti-inflammatory drugs, perhaps also in combinations with monoclonal antibodies. New ways of administration may be important and/or DNAvaccines may be found to be another effective way of creating tolerance against auto-antigens, In spite of recent failures of some immune interventions in clinical trials knowledge is growing and there may soon be a breakthrough.

\section{Disclosure}

Diamyd Medical was sponsor for the Phase II/III GAD-alum trials and has also given financial support for the investigator-initiated mechanistic studies of this type of therapy. Honorarium for lectures has been received from NovoNordisk, Lilly and SanofiAventis. The author is also member of Advisory Board of LifeScan.

\section{Acknowledgements}

In addition to the author the Linköping Diabetes Immune Intervention study group consists of Ass.professor Rosaura Casas, PhD, Stina Axelsson PhD, Mikael Cheramy PhD, and PhD students Mikael Pihl and Linda Åkerman. 
We are grateful to excellent technical assitance from Ingela Johansson and Gosia Smolinska, and from research nurses Eva Isacson and AnnMarie Sandström. All pediatricians involved in our studies are also gratefully acknowledged.

Our studies on immune intervention have been generously supported by Barndiabetesfonden (Swedish Child Diabetes Foundation), Swedish Research Council, Research Council of Southeast Sweden ( FORSS), and the mechanistic studies are supported by Juvenile Diabetes Research Foundation (JDFR).

\section{Author details}

Johnny Ludvigsson

Dept of Clin Exp Med, Linköping university, Linköping, Sweden

\section{References}

[1] Aanstoot HJ, Anderson BJ, Daneman D, Danne T, Donaghue K, Kaufman F, Réa RR, Uchigata Y.The global burden of youth diabetes: perspectives and potential. Pediatr Diabetes. 2007 Oct;8 Suppl 8:1-44.

[2] The Diabetes Control and Complications Trial Research Group. The effect of intensive treatment of diabetes on the development and progression of long-term complications in insulin-dependent diabetes mellitus. N Engl J Med 1993;329:977-86.

[3] Bojestig M, Arnqvist HJ, Hermansson G, Karlberg BE, Ludvigsson J. Declining incidence of nephropathy in insulin-dependent diabetes mellitus. $N$ Engl J Med 1994;330:15-8

[4] Wild D, Von Maltzahn R, Brohan E, Christensen T, Clauson P, Gonder-Frederick L. A critical review of the literature on fear of hypoglycemia in diabetes: Implications for diabetes management and patient education. Patient Educ Couns. 2007;68:10-15

[5] Tamborlane WV, Beck RW, Bode BW, Buckingham B, Chase HP, Clemons R, FialloScharer R, Fox LA, Gilliam LK, Hirsch IB, Huang ES, Kollman C, Kowalski AJ, Laffel L, Lawrence JM, Lee J, Mauras N, O'Grady M, Ruedy KJ, Tansey M, Tsalikian E, Weinzimer S, Wilson DM, Wolpert H, Wysocki T, Xing D. Continuous glucose monitoring and intensive treatment of type 1 diabetes. N Engl J Med. 2008;359:1464-1476.

[6] Choudhary P, Shin J, Wang Y, Evans ML, Hammond PJ, Kerr D, Shaw JA, Pickup JC, Amiel SA. Insulin pump therapy with automated insulin suspension in response to hypoglycemia: reduction in nocturnal hypoglycemia in those at greatest risk. Diabetes Care. 2011;34:2023-2025. 
[7] Danne T, Kordonouri O, Holder M, Haberland H, Golembowski S, Remus K, Blasig S, Wadien T, Zierow S, Hartmann R, Thomas A. Prevention of hypoglycemia by using low glucose suspend function in sensor-augmented pump therapy. Diabetes Technol Ther. 2011;13:1-6

[8] Hovorka R. Closed-loop insulin delivery: from bench to clinical practice. Nat Rev Endocrinol. 2011;7:385-395.

[9] Hovorka R, Allen JM, Elleri D, Chassin LJ, Harris J, Xing D, Kollman C, Hovorka T, Larsen AM, Nodale M, De PA, Wilinska ME, Acerini CL, Dunger DB. Manual closedloop insulin delivery in children and adolescents with type 1 diabetes: a phase 2 randomised crossover trial. Lancet. 2010;375:743-751

[10] Madsbad S, Alberti KG, Binder C, Burrin JM, Faber OK, Krarup T, and Regeur L: Role of residual insulin secretion in protecting against ketoacidosis in insulin-dependent diabetes. Br Med J 2: 1257-1259, 1979.

[11] Steffes MW, Sibley S, Jackson M, Thomas W. Beta-cell function and the development of diabetes-related complications in the Diabetes Control and Complications Trial. Diabetes Care 2003;26:832-6.

[12] Wahren J, Ekberg K, Jörnvall H. C-peptide is a bioactive peptide. Diabetologia. 2007 Mar;50(3):503-9.

[13] Jun HS. Regeneration of pancreatic beta cells. Front Biosci. 2008 May 1;13:6170-82

[14] Gonez LJ, Knight KR. Cell therapy for diabetes: stem cells, progenitors or beta-cell replication?Mol Cell Endocrinol. 2010 Jul 8;323(1):55-61.

[15] Ludvigsson J. C-peptide an adequate endpoint in type 1 diabetes. Diabetes Metab Res Rev. 2009 Nov;25(8):691-3.

[16] Bottazzo GF, Florin-Christensen A, Doniach D. Islet-cell antibodies in diabetes mellitus with autoimmune polyendocrine deficiencies. Lancet 1974:2:1279-82.

[17] Palmer JP, Asplin CM, Clemons P, Lyen K, Tatpati O, Raghu PK, Paquette TL. Insulin antibodies in insulin-dependent diabetics before insulin treatment. Science. 1983 Dec 23;222(4630):1337-9.

[18] Baekkeskov S. Immunoreactivity to a $64,000 \mathrm{Mr}$ human islet cell antigen in sera from insulin-dependent diabetes mellitus patients and individuals with abnormal glucose tolerance. Mol Biol Med. 1986 Apr;3(2):137-42

[19] Savola K, Bonifacio E, Sabbah E, et al. IA-2 antibodies - a sensitive marker of IDDM with clinical onset in childhood and adolescence. Diabetologia 1998:41:424-9.

[20] Wenzlau JM, Juhl K, Yu L, et al. The cation efflux transporter ZnT8 (Slc30A8) is a major autoantigen in human type 1 diabetes. Proc Natl Acad Sci U S A. 2007;104:17040-5. 
[21] Ludvigsson J, Heding L, Lieden G, Marner B, Lernmark A. Plasmapheresis in the initial treatment of insulin-dependent diabetes mellitus in children. Br Med J (Clin Res Ed) 1983;286:176-8.

[22] Dupre J, Stiller CR, Gent M, et al. Clinical Trials of Cyclosporin in IDDM. Diabetes Care 1988;suppl 1:37-44

[23] Eisenbarth GS, Srikanta S, Jackson R, et al. Anti-thymocyte globulin and prednisone immunotherapy of recent onset type 1 diabetes mellitus. Diabetes Research 1985;2:271-6

[24] Chase HP, Butler-Simon N, Garg S, McDuffie M, Hoops SL, O’Brien D. A trial of nicotinamide in newly diagnosed patients with type 1 (insulin-dependent) diabetes mellitus. Diabetologia 1990;33:444-6

[25] Pozzilli P, Visalli N, Signore A, et al. Double blind trial of nicotinamide in recent-onset IDDM (the IMDIAB III study). Diabetologia 1995;38:848-52.

[26] Coutant R, Landais P, Rosilio M, et al. Low dose linomide in Type I juvenile diabetes of recent onset: a randomised placebo-controlled double blind trial. Diabetologia 1998;41:1040-6.

[27] Ludvigsson J, Samuelsson U, Johansson C, Stenhammar L. Treatment with antioxidants at onset of type 1 diabetes in children: a randomized, double-blind placebo-controlled study. Diabetes Metab Res Rev 2001;17:131-6.

[28] Ludvigsson J, Samuelsson U, Ernerudh J, Johansson C, Stenhammar L, Berlin G. Photopheresis at onset of type 1 diabetes: a randomised, double blind, placebo controlled trial. Arch Dis Child 2001;85:149-54.

[29] Herold KC, Gitelman SE, Masharani U, et al. A single course of anti-CD3 monoclonal antibody hOKT3gamma1(Ala-Ala) results in improvement in C-peptide responses and clinical parameters for at least 2 years after onset of type 1 diabetes. Diabetes 2005;54:1763-9.

[30] Keymeulen B, Vandemeulebroucke E, Ziegler AG, et al. Insulin needs after CD3-antibody therapy in new-onset type 1 diabetes. N Engl J Med 2005;352:2598-608.

[31] Keymeulen B, Walter M, Mathieu C, Kaufman L, Gorus F, Hilbrands R, Vandemeulebroucke E, Van de Velde U, Crenier L, De Block C, Candon S, Waldmann H, Ziegler AG, Chatenoud L, Pipeleers D. Four-year metabolic outcome of a randomised controlled CD3-antibody trial in recent-onset type 1 diabetic patients depends on their age and baseline residual beta cell mass. Diabetologia. 2010 Apr;53(4):614-23.

[32] Pescovitz MD, Greenbaum CJ, Krause-Steinrauf H, Becker DJ, Gitelman SE, Goland R, Gottlieb PA, Marks JB, McGee PF, Moran AM, Raskin P, Rodriguez H, Schatz DA, Wherrett D, Wilson DM, Lachin JM, Skyler JS; Type 1 Diabetes TrialNet Anti-CD20 Study Group Rituximab, B-lymphocyte depletion, and preservation of beta-cell function. N Engl J Med. 2009 Nov 26;361(22):2143-52. 
[33] Gottlieb et al Abstract Annual Meeting of ADA, 2011.

[34] Sherry N, Hagopian W, Ludvigsson J, Jain SM et al Teplizumab for treatment of type 1 diabetes (Protégé study): 1-year results from a randomised, placebo-controlled trial. Lancet. 2011 Aug 6;378(9790):487-97

[35] Gundersen E: Is Diabetes of Infectious Origin? The Journal of Infectious Diseases, Vol. 41, No. 3 (Sep., 1927), pp. 197-202..

[36] Hiltunen M, Lönnrot M, Hyöty H. Immunisation and type 1 diabetes mellitus: is there a link? Drug Saf. 1999 Mar;20(3):207-12.

[37] Lindberg B, Ahlfors K, Carlsson A, Ericsson UB, Landin-Olsson M, Lernmark A, Ludvigsson J, Sundkvist G, Ivarsson SA. Previous exposure to measles, mumps, and rubella--but not vaccination during adolescence--correlates to the prevalence of pancreatic and thyroid autoantibodies. Pediatrics. 1999 Jul;104(1):e12

[38] Hviid A, Stellfeld M, Wohlfahrt J, Melbye M.. Childhood vaccination and type 1 diabetes. N Engl J Med. 2004 Apr 1;350(14):1398-404

[39] Hyöty H, Hiltunen M, Knip M, Laakkonen M, Vähäsalo P, Karjalainen J, Koskela P, Roivainen M, Leinikki $\mathrm{P}$, Hovi $\mathrm{T}$, et al. A prospective study of the role of coxsackie B and other enterovirus infections in the pathogenesis of IDDM. Childhood Diabetes in Finland (DiMe) Study Group. Diabetes. 1995 Jun;44(6):652-7

[40] Yoon JW, Austin M, Onodera T, Notkins AL. Isolation of a virus from the pancreas of a child with diabetic ketoacidosis.N Engl J Med. 1979 May 24;300(21):1173-9

[41] Allen HF, Klingensmith GJ, Jensen P, Simoes E, Hayward A, Chase HP. Effect of Bacillus Calmette-Guerin vaccination on new-onset type 1 diabetes. A randomized clinical study. Diabetes Care. 1999 Oct;22(10):1703-7

[42] Vaarala O. The role of the gut in beta-cell autoimmunity and type 1 diabetes: a hypothesis. Pediatr Diabetes. 2000 Dec;1(4):217-25

[43] Virtanen SM, Knip M. Nutritional risk predictors of beta cell autoimmunity and type 1 diabetes at a young age. Am J Clin Nutr. 2003 Dec;78(6):1053-67

[44] Vaarala O. Is it dietary insulin? Ann N Y Acad Sci. 2006 Oct;1079:350-9.

[45] Benno Y, Mitsuoka T. Development of intestinal microflora in humans and animals. Bififidobacteria Microfl 1986;5:13-25.

[46] Matsuzaki T, Nagata Y, Kado S, et al. Prevention of onset in an insulin-dependent diabetes mellitus model, NOD mice, by oral feeding of Lactobacillus casei. APMIS 1997;105:643-9.

[47] Calcinaro F, Dionisi S, Marinaro M, et al. Oral probiotic administration induces interleukin-10 production and prevents spontaneous autoimmune diabetes in the non-obese diabetic mouse. Diabetologia. 2005;48:1565-75 
[48] .Elias D, Cohen IR Treatment of autoimmune diabetes and insulitis in NOD mice with heat shock protein 60 peptide p277. Diabetes. 1995 Sep;44(9):1132-8

[49] Raz I, Elias D, Avron A, Tamir M, Metzger M, Cohen IR. Beta-cell function in new-onset type 1 diabetes and immunomodulation with a heat-shock protein peptide (DiaPep277): a randomised, double-blind, phase II trial. Lancet. 2001 Nov 24;358(9295): 1749-53

[50] Lazar L, Ofan R, Weintrob N, et al. Heat-shock protein peptide DiaPep277 treatment in children with newly diagnosed type 1 diabetes: a randomised, double-blind phase II study. Diabetes Metab Res Rev 2007 May;23(4):286-91

[51] Schloot NC, Meierhoff G, Lengyel C, Vándorfi G, Takács J, Pánczél P, Barkai L, Madácsy L, Oroszlán T, Kovács P, Sütö G, Battelino T, Hosszufalusi N, Jermendy G. Effect of heat shock protein peptide DiaPep277 on beta-cell function in paediatric and adult patients with recent-onset diabetes mellitus type 1: two prospective, randomized, double-blind phase II trials. Diabetes Metab Res Rev. 2007

[52] Huurman VA, van der Meide PE, Duinkerken G, Willemen S, Cohen IR, Elias D, Roep BO. Immunological efficacy of heat shock protein 60 peptide DiaPep277 therapy in clinical type I diabetes. Clin Exp Immunol. 2008 Jun;152(3):488-97.

[53] Schloot N et al: Abstract IDS, Victoria 2012

[54] Raz I et al Abstract ADA 2012

[55] Theodoropoulos DS, Lockey RF. Allergen immunotherapy: guidelines, update, and recommendations of the World Health Organization. Allergy Asthma Proc. 2000 MayJun;21(3):159-66.

[56] Ludvigsson J. Adequate doses of autoantigen administered using the appropriate route may create tolerance and stop autoimmunity. Diabetologia 2009;52 (1):

[57] Castermans E, Baron F, Willems E, Schaaf-Lafontaine N, Meuris N, Gothot A, Vanbellighen JF, Herens C, Seidel L, Geenen V, Cheynier R, Beguin Y. Evidence for neo-generation of $\mathrm{T}$ cells by the thymus after non-myeloablative conditioning. Haematologica. 2008 Feb;93(2):240-7.

[58] Klein L, Hinterberger M, Wirnsberger G, Kyewski B. Antigen presentation in the thymus for positive selection and central tolerance induction. Nat Rev Immunol. 2009 Dec; 9(12):833-44.

[59] Pozzilli P. The DPT-1 trial: a negative result with lessons for future type 1 diabetes prevention. Diabetes Metab Res Rev. 2002 Jul-Aug;18(4):257-9

[60] Skyler JS, Krischer JP, Wolfsdorf J, Cowie C, Palmer JP, Greenbaum C, Cuthbertson D, Rafkin-Mervis LE, Chase HP, Leschek E. Effects of oral insulin in relatives of patients with type 1 diabetes: The Diabetes Prevention Trial--Type 1. Diabetes Care. 2005 
[61] Every AL, Kramer DR, Mannering SI, Lew AM, Harrison LC. Intranasal vaccination with proinsulin DNA induces regulatory CD4+ T cells that prevent experimental autoimmune diabetes. J Immunol. 2006 Apr 15;176(8):4608-15

[62] .Näntö-Salonen K, Kupila A, Simell S, Siljander H, Salonsaari T, Hekkala A, Korhonen S, Erkkola R, Sipilä JI, Haavisto L, Siltala M, Tuominen J, Hakalax J, Hyöty H, Ilonen J, Veijola R, Simell T, Knip M, Simell O. Nasal insulin to prevent type 1 diabetes in children with HLA genotypes and autoantibodies conferring increased risk of disease: a double-blind, randomised controlled trial. Lancet. 2008 Nov 15;372(9651):1746-55.

[63] Song HY, Abad MM, Mahoney CP, McEvoy RC. Human insulin B chain but not A chain decreases the rate of diabetes in BB rats. Diabetes Res Clin Pract. 1999 Nov;46(2):109-14)

[64] Orban T, Farkas K, Jalahej H, Kis J, Treszl A, Falk B, Reijonen H, Wolfsdorf J, Ricker A, Matthews JB, Tchao N, Sayre P, Bianchine P. Autoantigen-specific regulatory T cells induced in patients with type 1 diabetes mellitus by insulin B-chain immunotherapy. J Autoimmun. 2010 Jun;34(4):408-15 Use of auto-antigens may be a way to modulate the immune process and increa<se T-cell regulation and tolerance.

[65] Baekkeskov S, Nielsen JH, Marner H, Bilde T, Ludvigsson J, Lernmark A. Autoantibodies in newly diagnosed diabetic children immunoprecipitate human pancreatic islet cell proteins. Nature 1982;298:167-9.

[66] Baekkeskov S, Aanstoot HJ, Christgau S, Reetz A, Solimena M, Cascalho M, Folli F, Richter-Olesen H, De Camilli P. Identification of the $64 \mathrm{~K}$ autoantigen in insulin-dependent diabetes as the GABA-synthesizing enzyme glutamic acid decarboxylase. Nature. 1990 Sep 13;347(6289):151-6

[67] Tian J, Clare-Salzler M, Herschenfeld A, et al. Modulating autoimmune responses to GAD inhibits disease progression and prolongs islet graft survival in diabetes-prone mice. Nature Medicine 1996;2:1348-53.

[68] Tisch R, Liblau RS, Yang XD, Liblau P, McDevitt HO. Induction of GAD65-specific regulatory $\mathrm{T}$ cells inhibits ongoing autoimmune diabetes in non-obese diabetic mice. Diabetes 1998;47:894-9.

[69] Agardh CD, Cilio CM, Lethagen A, et al. Clinical evidence for the safety of GAD65 immunomodulation in adult-onset autoimmune diabetes. J Diabetes Complications 2005;19:238-46.

[70] Agardh C-D, Lynch K, Palmér M, Link K et al. GAD65 vaccination significantly reduces insulin dependence at five years follow-up in a dose escalating study in adult-onset autoimmune diabetes patients. Diabetologia 51 2008;(suppl.1):S230.

[71] Ludvigsson J, Faresjo M, Hjorth M, Axelsson S, Cheramy M, Pihl M, et al. GAD treatment and insulin secretion in recent-onset type 1 diabetes. N Engl J Med. 2008;359(18): 1909-20. 
[72] Ludvigsson J, Hjorth M, Chéramy M, Axelsson S et al Extended evaluation of the safety and efficacy of GAD treatment of children and adolescents with recent-onset type 1 diabetes: a randomised controlled trial. Diabetologia. 2011 Mar;54(3):634-40.

[73] Ludvigsson J, Krisky D, Casas R, Battelino T et al GAD65 antigen therapy in recently diagnosed type 1 diabetes mellitus. N Engl J Med. 2012 Feb 2;366(5):433-42

[74] Chéramy M, Skoglund C, Johansson I, Ludvigsson J, Hampe CS, Casas R. GAD-alum treatment in patients with type 1 diabetes and the subsequent effect on GADA IgG subclass distribution, GAD(65) enzyme activity and humoral response. Clin Immunol. 2010 Jun 25.

[75] Axelsson S, Chéramy M, Hjorth M, Pihl M, et al Long-lasting immune responses 4 years after GAD-alum treatment in children with type 1 diabetes. PLoS One. 2011;6(12):e29008.

[76] Hjorth M, Axelsson S, Rydén A, Faresjö M, Ludvigsson J et al GAD-alum treatment induces GAD65-specific CD4+CD25highFOXP3+ cells in type 1 diabetic patients. Clin Immunol. 2011 Jan;138(1):117-26

[77] Wherrett DK, Bundy B, Becker DJ, et al. Antigen-based therapy with glutamic acid decarboxylase (GAD) vaccine in patients with recent-onset type 1 diabetes: a randomised double-blind trial. Lancet. 2011 Jul 23;378(9788):319-27.

[78] von Herrath MG, Whitton JL DNA vaccination to treat autoimmune diabetes. Ann Med. 2000 Jul;32(5):285-92.

[79] Zhang W, Jin H, Hu Y, Yu Y, Li X, Ding Z, Kang Y, Wang B. Protective response against type 1 diabetes in nonobese diabetic mice after coimmunization with insulin and DNA encoding proinsulin. Hum Gene Ther. 2010 Feb;21(2):171-8.

[80] Bot A, Smith D, Bot S, Hughes A, Wolfe T, Wang L, Woods C, von Herrath M. Plasmid vaccination with insulin $B$ chain prevents autoimmune diabetes in nonobese diabetic mice. J Immunol. 2001 Sep 1;167(5):2950-5.

[81] Tisch R, Wang B, Weaver DJ, Liu B, Bui T, Arthos J, Serreze DV.Antigen-specific mediated suppression of beta cell autoimmunity by plasmid DNA vaccination. J Immunol. 2001 Feb 1;166(3):2122-32

[82] Weaver DJ Jr, Liu B, Tisch R. Plasmid DNAs encoding insulin and glutamic acid decarboxylase 65 have distinct effects on the progression of autoimmune diabetes in nonobese diabetic mice. J Immunol. 2001 Jul 1;167(1):586-92.

[83] Jun HS, Chung YH, Han J, Kim A, Yoo SS, Sherwin RS, Yoon JW. Prevention of autoimmune diabetes by immunogene therapy using recombinant vaccinia virus expressing glutamic acid decarboxylase. Diabetologia. 2002 May;45(5):668-76

[84] Rother KI, Spain LM, Wesley RA, Digon BJ 3rd, Baron A, Chen K, Nelson P, Dosch HM, Palmer JP, Brooks-Worrell B, Ring M, Harlan DM. Effects of exenatide alone and in 
combination with daclizumab on beta-cell function in long-standing type 1 diabetes. Diabetes Care. 2009 Dec;32(12):2251-7.

[85] Dungan KM, Buse JB, Ratner RE. Effects of therapy in type 1 and type 2 diabetes mellitus with a peptide derived from islet neogenesis associated protein (INGAP). Diabetes Metab Res Rev. 2009 Sep;25(6):558-65.

[86] Hyppönen E, Läärä E, Reunanen A, Järvelin MR, Virtanen SM.: Intake of vitamin D and risk of type 1 diabetes; a birth-cohort study. Lancet 2001; 358: 1500-1503.

[87] Zipitis CS, Akobeng AK.: Vitamin D supplementation in early childhood and risk of type 1 diabetes: a systematic review and meta-analysis. Arch Dis Child 2008; 93: 512517

[88] Markus Walter, MD,1 Thomas Kaupper, MD,1 Kerstin Adler, PHD,1 Johannes Foersch, 1 Ezio Bonifacio, PHD,2 and Anette-G. Ziegler, No Effect of the 1 $\alpha, 25$-Dihydroxyvitamin D3 on $\beta$-Cell Residual Function and Insulin Requirement in Adults With NewOnset Type 1 Diabetes. Diabetes Care. 2010 July; 33(7): 1443-1448

[89] .Carla Bizzarri, MD, ${ }^{1}$ Dario Pitocco, $\mathrm{MD},{ }^{2}$ Nicola Napoli, MD, ${ }^{3}$ Enrico Di Stasio, MD, ${ }^{2}$ Daria Maggi, MD, ${ }^{3}$ Silvia Manfrini, $\mathrm{MD},{ }^{3}$ Concetta Suraci, $\mathrm{MD},{ }^{4}$ Maria Gisella Cavallo, MD, ${ }^{5}$ Marco Cappa, MD, ${ }^{1}$ Giovanni Ghirlanda, MD, ${ }^{2}$ Paolo Pozzilli, MD, ${ }^{3}$ and the IMDIAB Group * No Protective Effect of Calcitriol on $\beta$-Cell Function in Recent-Onset Type 1 Diabetes.The IMDIAB XIII trial. Diabetes Care. 2010 September; 33(9): 1962-1963

[90] Pickersgill LM, Mandrup-Poulsen TR. The anti-interleukin-1 in type 1 diabetes action trial--background and rationale. Diabetes Metab Res Rev. 2009 May;25(4):321-4. Review

[91] Greenbaum C. Abstract IDS 2012

[92] Mandrup-Poulsen T: Abstract IDS 2012 
